Annals of Warsaw University of Life Sciences - SGGW

Land Reclamation No 43 (1), 2011: 37-46

(Ann. Warsaw Univ. of Life Sci. - SGGW, Land Reclam. 43 (1), 2011)

\title{
Recorded lag times of snowmelt events in a small catchment
}

\author{
AGNIESZKA HEJDUK, KAZIMIERZ BANASIK \\ Department of Water Engineering, Warsaw University of Life Sciences - SGGW
}

\begin{abstract}
Recorded lag times of snowmelt events in a small catchment. The hydrological and meteorological data collected in small, lowland catchment during snowmelt floods have been used to calculate lag time of runoff ( $\mathrm{Lag})$ and lag time of sediment yield ( $\operatorname{Lag}_{s}$ ). Both, Lag and $\mathrm{Lag}_{s}$ are important characteristics of the instantaneous unit hydrograph (IUH) and instantaneous unit sedimentgraph (IUSG). Field data from Zagożdżonka River catchment have been used to demonstrate the relationship between lag times. The results of investigation show that: a) there is a strong relationship between $\mathrm{Lag}$ and $\mathrm{Lag}_{s}$; b) in most cases the value of a $=\operatorname{Lag}_{s} / \operatorname{Lag}$ is smaller than $1 ; \mathrm{c}$ ) in case of snowmelt floods there was only poor correlation between parameter a and the total runoff depth (water supply).
\end{abstract}

Key words: snowmelt floods, suspendent sediment transport, lag time of runoff and sediment yield.

\section{INTRODUCTION}

Rapid snowmelt due to sudden warming or periodic rain-on-snow events is a common cause of spring flooding. Monitoring and mathematical describing of the processes would help predict snowmelt patterns and assist forecasters in predicting snowmelt-related flooding and transport of sediments. The graph of suspended sediment load (sedimentgraph) associated with hydrograph caused by rainfall plays an important role in rainfall-runoff-sediment transport modeling. An important part of the procedure of sedimentgraph estimation is the instantaneous unit sedimentgraph (IUSG), which is based on instantaneous unit hydrograph $(I U H)$ concept. The idea of sedimentgraph, introduced by Williams (1978), was the basis for the new definition of IUSG presented by Banasik (Banasik 1994a; 1995; Banasik and Walling 1996; Banasik et al. 2006; Banasik and Mitchell 2008). The IUSG has been incorporated into the sedimentgraph model (SEGMO), which consists of two sub-models: sedimentology submodel and hydrologic one. The hydrologic submodel uses CN metod (Banasik et al. 2000) to estimate effective rainfal and the $I U H$ procedure to transform it into the direct runoff hydrograph. The sedimentology sub-model uses Universal Soil Loss Equation (Sonnevel and Nearing 2003; Banasik and Górski 1992) to estimate the amount of suspended sediment produced during the event and the IUSG procedure to transform the produced sediment into a sedimentograph. As the number of application of sediment graph models is increasing (Bhunya et al. 2009; Sadeghi and Singh 2005; Singh at al. 2008), because of the increasing importance of water quality prediction, the estimation of lag times on recorded events is very required.

The lag time of runoff $(\mathrm{Lag})$ and lag time of sediment yield $\left(\operatorname{Lag}_{S}\right)$ are characteristics of IUH and IUSG. Lag is defined as the time elapsed between the centro- 
ids of the effective rainfall and the direct runoff hydrograph (Banasik et al. 2006) Lag time of sedimentgraph is defined as the distance measured in the time scale between the center of gravity of the temporal distribution of sediment and sedimentgraph. The relationship between lag times $\left(\operatorname{Lag}_{s} / \mathrm{Lag}\right)$ is used to estimate sediment routing coefficient $(B)$, which is a key parameter of IUSG. Both, Lag and $\operatorname{Lag}_{s}$ can be calculated using rainfall-runoff-suspended sediment data.

\section{CALCULATION AND USE OF LAG TIME OF DIRECT RUNOFF AND SUSPENDED SEDIMENT IN CASE OF SNOWMELT FLOOD}

Both, lag time of hydrograph ( $\mathrm{Lag}$ ) and lag time of sedimentgraph $\left(\operatorname{Lag}_{s}\right)$ are the characteristic values of the instantaneous unit hydrograph (IUH) and the instantaneous unit sedimentgraph (IUSG) procedures. These characteristics are interrelated.

For rainfall flood $L a g$ and $\operatorname{Lag}_{s}$ can be calculated using rainfall-runoff-suspended sediment data (Banasik 1995):

$$
\mathrm{Lag}=\mathrm{M}_{1 \mathrm{Q}}-\mathrm{M}_{1 \mathrm{P}}
$$

where:

Lag - lag time of hydrograph (h), $\mathrm{M}_{1 \mathrm{Q}}$ - first statistical moment of the direct runoff hydrograph (h),

$\mathrm{M}_{1 \mathrm{P}}$ - first statistical moment of the effective rainfall hyetograph (h);

and

$\operatorname{Lag}_{\mathrm{s}}=\mathrm{M}_{1 \mathrm{~S}}-\mathrm{M}_{1 \mathrm{E}}$

where:

$\mathrm{Lag}_{s}$ - lag time of sedimentgraph (h),
$\mathrm{M}_{1 \mathrm{~S}}$ - first statistical moment of the graph of direct suspended sediment rate $(\mathrm{h})$, $M_{1 E}$ - first statistical moment of the graph of sediment production (h).

Estimating lag times for snowmelt floods is similar to the procedure presented for rainfall events. Snowmelt-runoff-suspended sediment data allow calculating lag times of snowmelt floods. The definitions of Lag and Lags during snowmelt flood illustrate the Figure 1.

Total water supply (rainfall and snowmelt), is divided on losses and effective supply. In case of snowmelt floods, total supply is calculated as a sum of daily water losses from the snow (counted from 7:00 am the day before to 7:00 am present day) and the rainfall. Using SCS method (SCS 1986), losses and effective supply (responsible for direct runoff) are calculated.

Direct runoff is a provoking factor for sediment production. There is a relationship between $\operatorname{Lag}_{s}$ and Lag, which can be written as:

$\operatorname{Lag}_{s}=a \cdot \operatorname{Lag}$

where $a$ is a parameter of the equation.

For the IUH derived by Nash, the lag time is estimated using the formula:

$\operatorname{Lag}=N \cdot k$

where:

$N$ - number of reservoirs (-),

$k$ - retention time of reservoir (h)

$\mathrm{Lag}_{s}$ can be calculated from the formula (Banansik and Walling 1996):

$\operatorname{Lag}_{s}=\frac{N \cdot k}{1+B \cdot k}$

where $B$ is sediment routing coefficient $\left(\mathrm{h}^{-1}\right)$. 


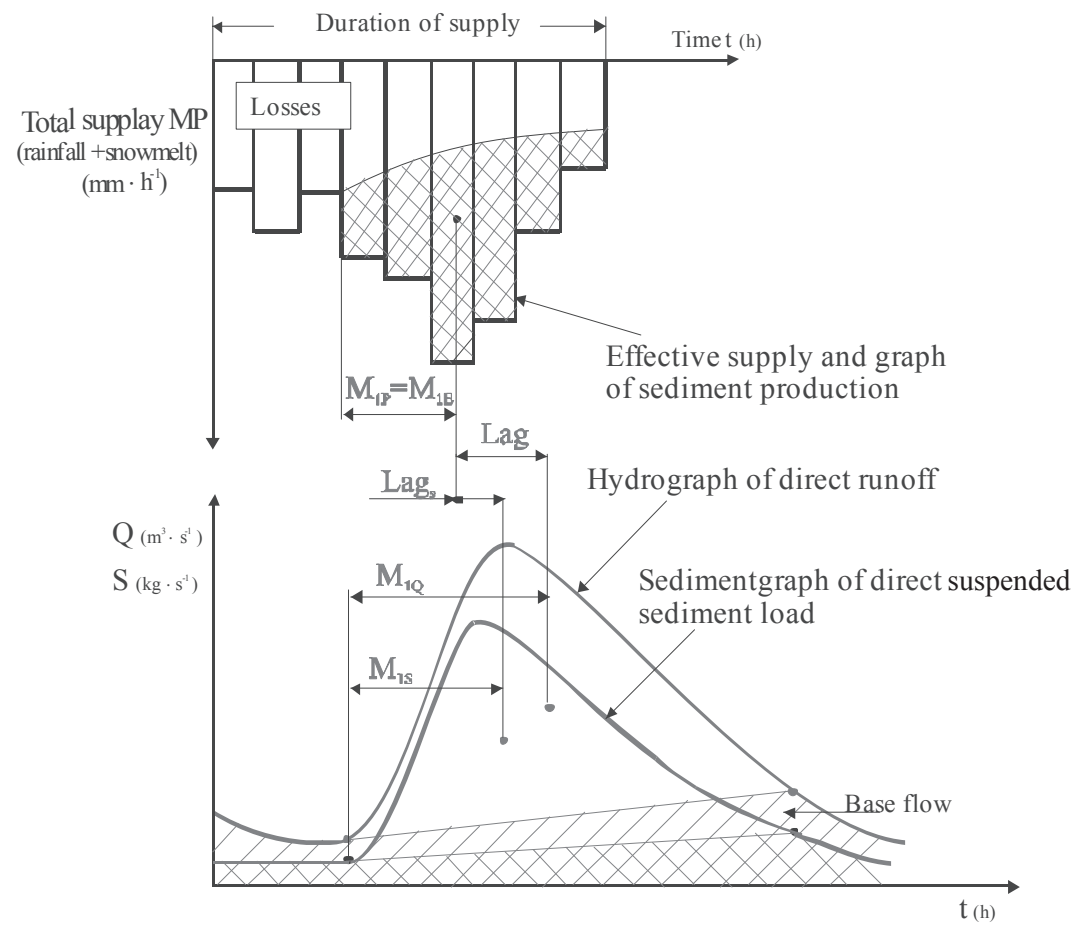

FIGURE 1. Lag time of runoff $(\mathrm{Lag})$ and lag time of suspended sediment yield $\left(\mathrm{Lag}_{s}\right)$ in snowmelt flood

Using the equations (4) and (5) coefficient $\mathrm{B}$ can be estimated from the formula:

$B=\left(\operatorname{Lag}_{L} \operatorname{Lag}_{s}-1\right) / k$

The parameters $N$ and $k$ can be determined on the basis of formulas described in the procedure of IUSG (Banasik 1994a; 1995; Banasik and Walling 1996; Banasik et al. 2006; Banasik and Mitchell 2008). The relationship between the $\operatorname{Lag}_{s}$ and Lag is used for empirical estimation of sediment routing coefficient $\mathrm{B}$.

\section{STUDY CATCHMENT}

Location, topography and area: The investigation was based on the data collected by the Department of Water Engi- neering, Warsaw University of Life Sciences - SGGW, from the $23.4 \mathrm{~km}^{2}$ lowland watershed of Zagożdżonka River at the Czarna gauging station. Zagożdżonka River, located in Central Poland (Fig. 2), about $100 \mathrm{~km}$ south of Warsaw is a left tributary of Vistula River. Local depressions don't contribute to direct runoff and sediment yield from the watershed. The catchment area, which contributes to direct runoff and sediment delivery to river system is $19.6 \mathrm{~km}^{2}$, upstream of Czarna gauge. Absolute relief is 26.5 $\mathrm{m}$ in the upper subcatchment (shown as $B$ in the Fig. 2), and $34 \mathrm{~m}$ in the entire watershed (A). The mean slopes of main streams are from $2.5 \mathrm{~m}$ to $3.5 \mathrm{~m}$ per 1000 m (Hejduk, Banasik 2010). 


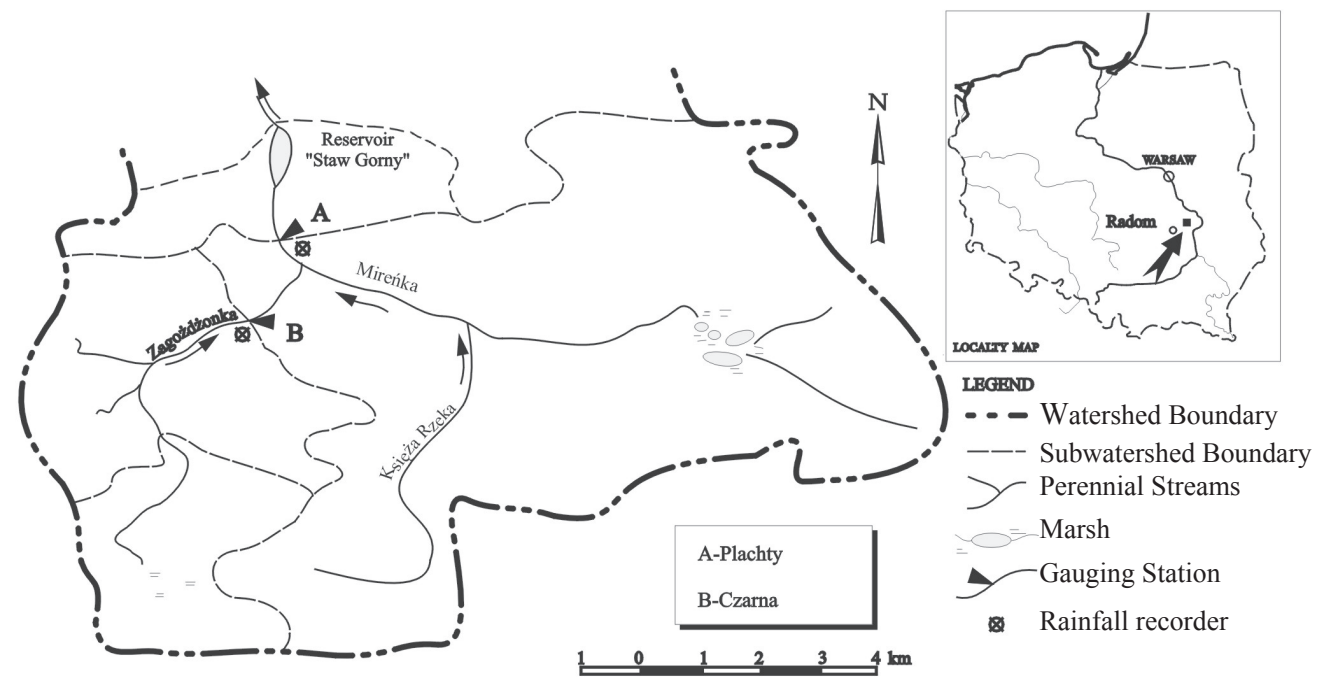

FIGURE 2. Locality map of the watershed

Land use and soils: The main type of soils are sandy soils (from almost pure to loamy sands), which covered $90 \%$ of watershed to Czarna gauging station. Also peaty soils may be found in local depressions and river flood plains. Land use in the watershed upstream of Czarna is dominated by arable land (potatoes and small grain). It covers $70 \%$ of the total area. $20 \%$ of area is covered by forest, $9.4 \%$ is pastures and $0.6 \%$ is paved areas.

Precipitation and runoff: The mean annual precipitation and runoff are estimated at $606 \mathrm{~mm}$ and $107 \mathrm{~mm}$ respectively. The average discharge of the 1963-2008 for Zagożdżonka River is $0.069\left(\mathrm{~m}^{3} / \mathrm{s}\right)$. The mean annual suspended sediment concentration ( $\mathrm{SSC}$ ) is low and has been estimated for ca $14 \mathrm{mg} / \mathrm{l}$ (Hejduk 2001; Hejduk et al. 2006). The snow cover usually appears between 25 -30 of November and disappears between 20-25 of March. The snowmelt period is usually $1-4$ days long (Hejduk 2009).

\section{METHODS OF FIELD INVESTIGATIONS}

All the calculations were based on rainfall and snowmelt-runoff-suspended sediment data measured on Czarna gauging station. Czarna gauging station is well equipped with electronic system of data collection. The data can be transmitted through Internet. Water level, turbidity, precipitation, air, soil and water temperature are measured with 10 minutes time step. During the winter the snow depth and snow water equivalent are measured at least once a day. Suspended sediment data are collected using the time integrated bathometers, self-acting bathometers, refrigerated samplers and settling tanks.

\section{MEASUREMENTS AND CHARACTERISTIC OF THE COLLECTED DATA}

River flow has been estimated based on the water level continuous records 
upstream of sharp-crested weir and its rating curve. Hydrometric measurements, which are taken several times in the hydrologic year, are the basis for the verification of the curve. Snowmelt periods were determined based on daily observations of snow, the course of air temperature and flow hydrographs. As the beginning of snowmelt period assumed the date on which the maximum temperature was above $0^{\circ} \mathrm{C}$ and simultaneously recorded water losses in the snow. The end of it was assumed as a date of complete disappearance of snow cover. General characteristics of the collected data are given in the Table 1. most cases was a small part of total supply (snowmelt and rainfall).

Lag times of runoff and suspended sediment yield have been calculated using computer program S3, which was developed in the Department of Water Engineering at Warsaw University of Life Sciences - SGGW. The program identifies the parameters of instantaneous unit hydrograph and instantaneous unit sedimentgraph (Banasik 1994b). Lag have been calculated for all 22 events, Lags have been calculated for 14 recorded floods with full suspended sediment data set. The results are presented in Table 2.

TABLE 1. General characteristic of 22 collected snowmelt events of Zagożdżonka River at Czarna gauge

\begin{tabular}{|l|c|c|}
\hline Category & Average & Range \\
\hline \multicolumn{1}{|c|}{1} & 2 & 3 \\
\hline Runoff $H(\mathrm{~mm})$ & 5.42 & $0.72-21.3$ \\
\hline Direct runoff, $H_{D}(\mathrm{~mm})$ & 3.42 & $0.26-16.3$ \\
\hline Peak discharge, $Q_{\max }\left(\mathrm{m}^{3} / \mathrm{s}\right)$ & 0.809 & $0.144-3.44$ \\
\hline$Q_{\max } /$ WQ50\% & 0.78 & $0.14-3.31$ \\
\hline Lag time of runoff $\operatorname{Lag}(\mathrm{h})$ & 17.1 & $7.14-31.8$ \\
\hline Lag time of sediment yield Lags $(\mathrm{h})$ & 14.3 & $4.99-30.9$ \\
\hline
\end{tabular}

Where $\mathrm{WQ}_{50} \%$ is two-year-flood discharge $=1.04 \mathrm{~m}^{3} / \mathrm{s}$.

\section{RESULTS AND DISCUSSION}

Snowmelt floods recorded in Zagożdżonka River catchment are mostly snowmelt-rainfall one. Recorded snowmelt periods were usually $1-4$ days long and they were accompanied by rainfall events, which also effected on size of the floods. The beginning of each snowmelt period was characterized by relatively large losses of water, which supplies the catchment (see Tab. 1). Effective supply $\left(M p_{e}\right)$ determined by SCS method, in
Calculated values of $\mathrm{Lag}$ contained in a range of 7.14-31.8 (h), with the average value at $17.1 \mathrm{(h}$ ) and a standard deviation of 5.98. Lag time of sedimentgraph contained in a range of 4.99-30.94 (h), average value was $14.30(\mathrm{~h})$ and the standard deviation 7.47. The lowest values of both lag times have been noted for flood number 8 and the highest for flood number 11 . The average difference between $\mathrm{Lag}$ and $\mathrm{Lag}_{s}$ have been calculated as 3.21 (h). In all cases, lag time of suspended sediment was shorter than 
TABLE 2. Characteristics of total $(M P)$ and effective $\left(M P_{e}\right)$ supply of water and lag times during snowmelt floods in Zagożdżonka River catchment.

\begin{tabular}{|c|c|c|c|c|c|c|}
\hline Lp. & $\begin{array}{c}\text { Begining of the } \\
\text { event }\end{array}$ & $\begin{array}{c}M P \\
(\mathrm{~mm})\end{array}$ & $\begin{array}{l}M P_{e} \\
(\mathrm{~mm})\end{array}$ & $\begin{array}{l}\text { Lag } \\
(\mathrm{h})\end{array}$ & $\begin{array}{l}\operatorname{Lag}_{s} \\
\text { (h) }\end{array}$ & $\begin{array}{c}a=\operatorname{Lag}_{S} / \operatorname{Lag} \\
(-)\end{array}$ \\
\hline 1 & $13-12-1998$ & 69.3 & 9.1 & 20.90 & - & - \\
\hline 2 & 01-12-1999 & 30.7 & 1.4 & 21.62 & - & - \\
\hline 3 & $03-01-2000$ & 21.8 & 0.8 & 20.13 & 11.37 & 0.56 \\
\hline 4 & 05-02-2001 & 21.3 & 0.7 & 19.47 & 12.56 & 0.64 \\
\hline 5 & 20-01-2002 & 55.4 & 4.2 & 25.60 & 24.42 & 0.95 \\
\hline 6 & 09-03-2003 & 23.9 & 5.2 & 15.04 & - & - \\
\hline 7 & 09-04-2003 & 41.8 & 7.0 & 14.54 & - & - \\
\hline 8 & 01-02-2004 & 34.9 & 0.4 & 7.14 & 4.99 & 0.70 \\
\hline 9 & $10-03-2004$ & 19.8 & 0.5 & 10.52 & 9.92 & 0.94 \\
\hline 10 & 04-01-2005 & 16.5 & 0.9 & 18.78 & - & - \\
\hline 11 & $22-02-2005$ & 10.0 & 1.7 & 31.78 & 30.94 & 0.97 \\
\hline 12 & 14-03-2005 & 59.9 & 16.2 & 17.42 & 15.77 & 0.91 \\
\hline 13 & $23-12-2005$ & 27.3 & 0.9 & 16.29 & 14.24 & 0.87 \\
\hline 14 & 25-03-2006 & 64.0 & 15.2 & 16.23 & 6.70 & 0.41 \\
\hline 15 & 05-11-2006 & 29.2 & 0.7 & 19.30 & 15.45 & 0.80 \\
\hline 16 & $28-01-2007$ & 19.0 & 0.3 & 14.18 & 11.82 & 0.83 \\
\hline 17 & 31-01-2007 & 21.9 & 3.6 & 8.06 & 5.36 & 0.67 \\
\hline 18 & 02-02-2007 & 10.4 & 2.0 & 12.62 & - & - \\
\hline 19 & 08-02-2007 & 13.9 & 1.1 & 15.34 & 13.42 & 0.88 \\
\hline 20 & 13-02-2007 & 22.1 & 1.3 & 23.69 & 23.29 & 0.98 \\
\hline 21 & 26-02-2009 & 29.4 & 1.3 & 18.93 & - & - \\
\hline 22 & 08-03-2009 & 24.4 & 0.8 & 7.52 & - & - \\
\hline Minimum & & 10.0 & 0.3 & 7.14 & 4.99 & 0.41 \\
\hline Maximum & & 69.3 & 16.2 & 31.8 & 30.9 & 0.98 \\
\hline Average & & 30.3 & 3.4 & 17.1 & 14.3 & 0.79 \\
\hline $\begin{array}{l}\text { Standard } \\
\text { deviation }\end{array}$ & & 17.2 & 4.49 & 5.98 & 7.47 & 0.17 \\
\hline
\end{tabular}

the lag time of runoff, which means that the culmination of wave of sediment is ahead of the culmination of water runoff (Fig. 3).

There is a linear relationship between $L a_{s}$ and $L a g$. For all analyzed events parameter $a=\operatorname{Lag}_{s} / \operatorname{Lag}$ has been found to be smaller than 1 (range $0.41-0.98$, with the average value 0.79 and standard deviation of 0.17 ). This relationship has been analyzed before by Banasik and Barszcz for 15 rain floods recorded in Zagożdżonka catchment between year 2000 and 2003. In 13 cases $a$ was less 


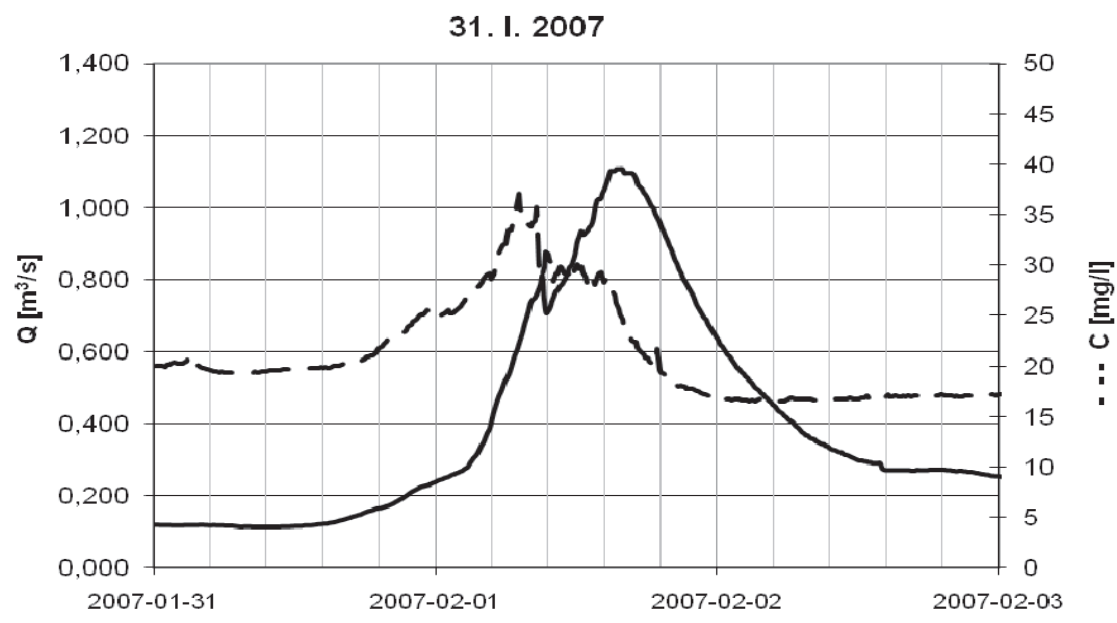

czas/time

FIGURE 3. The example of snowmelt flood in Zagożdżonka catchment

than 1 (Banasik and Barszcz 2006; Banasik et al. 2006).

Both, Lag and $\operatorname{Lag}_{s}$ are longer for snowmelt floods than for rainfall events, recorded in the same cachment. For rainfall floods recorded between 2006 and 2008 the range of variability of $\mathrm{Lag}$ was $1.63-13.14(\mathrm{~h})$, with an average 6.49 (h) and a standard deviation of 3.36. Lag time of sediment yield contained in range 2.94-12.7 (h), with average value 7.29 (h), and a standard deviation 3.08. Range of variability of $\mathrm{Lag}_{s} / \mathrm{Lag}$ was $0.66-1.05$ with the average value 0.91 and the standard deviation of 0.13 (Banasik 2009). The average values of $\mathrm{Lag}$ and $\mathrm{Lag}_{s}$ for snowmelt floods are twice longer then in case of rainfall events recorded in the same catchment and calculated by the same method. The reason for this might be the time distribution of snowmelt process. Total supply in case of snowmelt flood is more extended in time than in case of rainfall event. For snowmelt floods the relationship be- tween $\operatorname{Lag}_{s}$ and $\operatorname{Lag}$ (shown on Fig. 4) can be written as:

$\operatorname{Lag}_{s}=0.84 \mathrm{Lag}$

with the coefficient of determination $\mathrm{R}^{2}$ $=0.81$.

Respective relation for eight rainfall events recorded in the same gauging station in the period of 2006-2008 (Banasik 2009) were presented as:

$\operatorname{Lag}_{s}=0.93 \mathrm{Lag}$

with the coefficient of determination $\mathrm{R}^{2}=0.89$

This ratio of $L_{a g} / L a g$ versus rainfall depth for rainfall events was analyzed earlier (Banasik and Barszcz 2006; Banasik et al. 2006). It has been found that the ratio of rainfall floods is decreasing with increasing rainfall depth. Such investigation has not been done for snowmelt events. In case of the analized snowmelt floods there was only poor correlation (i.e. statisticaly insignificant relationship, with $\mathrm{R}^{2}=0.127$ ) between 


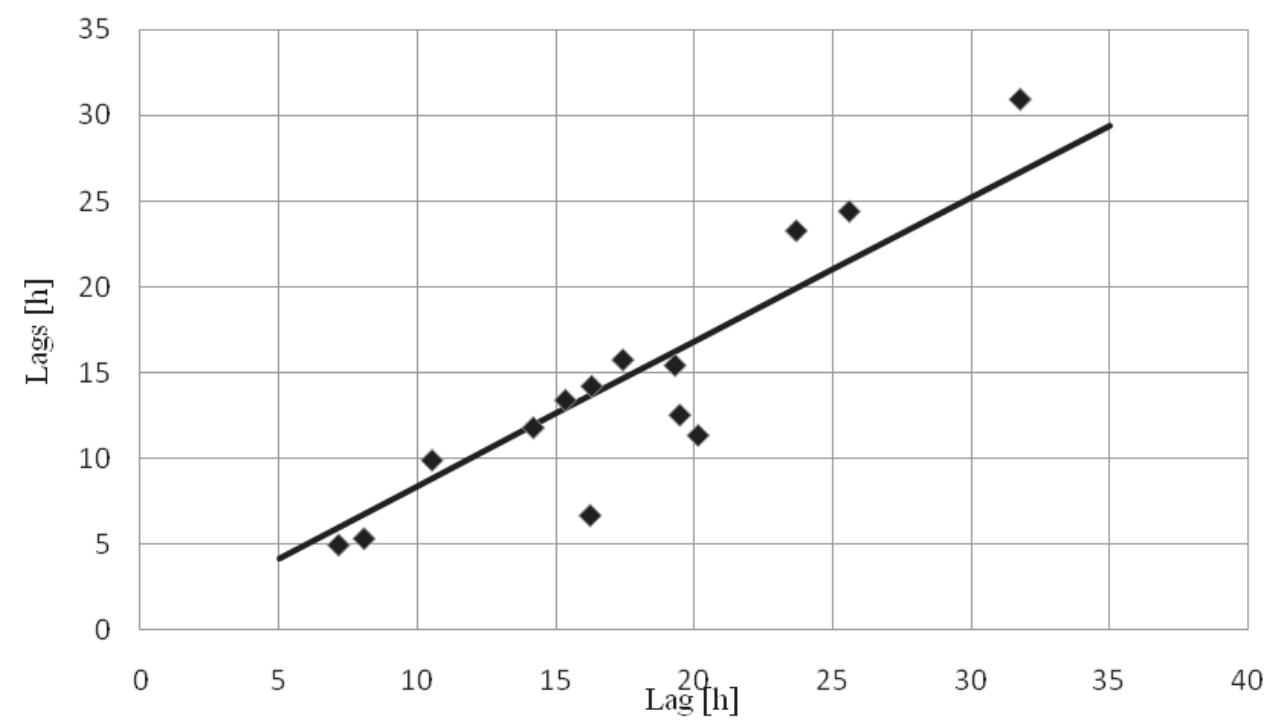

FIGURE 4. The relationship between $\mathrm{Lag}_{s}$ and $\mathrm{Lag}$ for snowmelt floods in Zagożdżonka catchment

parameter $a\left(a=\operatorname{Lag}_{s} / \operatorname{Lag}\right)$ and the total runoff depth (water supply), what is presented on Figure 5.

\section{CONCLUSIONS}

After taking into account the specificities of supply of the catchment during snowmelt period, lag times of hydrograph and suspended sediment yield during snowmelt flood can be calculated using the same, known methods which are used in case of rainfall floods. Results of analysis for 14 snowmelt events show, the lag time of sedimentgraph is shorter than the lag time of hydrograph. Both, $\operatorname{Lag}_{s}$ and Lag are longer in case of snowmelt flood than in case of rainfall one, recorded in this same catchment. There is significant linear relationship between Lags and Lag. The values of $a=\operatorname{Lag}_{s} / \mathrm{Lag}$ in all analyzed cases was less than 1 . There was only poor correlation between parameter $a$ and the total runoff depth .

\section{Acknowledgment}

The investigation has been carried out with financial support by a grant from Iceland, Liechtenstein and Norway through the EEA Financial Mechanism and the Norwegian Financial Mechanism and Resource for Sciences (2008-2011), as well as by Polish Ministry of Sciences and Higher Education. The support provided by these organizations is gratefully acknowledged.

\section{REFERENCES}

BANASIK K. 1994a: Model sedymentogramu wezbrania opadowego w małej zlewni rolniczej (Sedimentgraph model of rainfall event in a small agricultural watershed). Theses \& Monographs of Warsaw Agricultural University - SGGW, Warsaw, Poland [Engl. summ.]. Wydawnictwo SGGW, Warsaw.

BANASIK K. 1994b: Opis programu SN3. Raport wewnętrzny (Description of computer program SN3, Personal communi- 


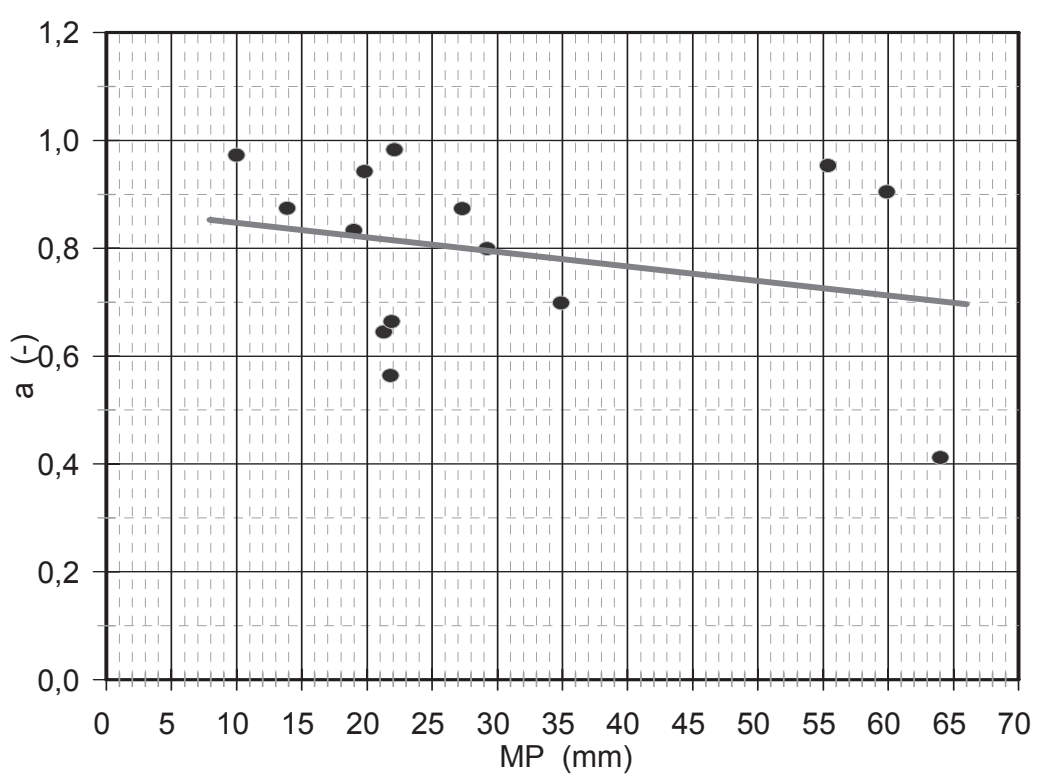

FIGURE 5. Relation between parameter a (a = Lags/Lag) and total supply (MP) for the snowmelt floods

cation). Warsaw University of Life Sciences - SGGW, Warsaw.

BANASIK K. 1995: A conceptual model of the instantaneous unit sediment graph. Sediment and Water Quality in River Catchments. Edited by: Foster I.D.L., Grunell A.M. \& Webb B.W. John Wiley \& Sons Ltd.

BANASIK K. (ed.) 2009: Lag times of flood runoff and sediment yield from small agricultural catchment. Research Report conducted within COST Action 634. Dept. of Water Engineering, Warsaw University of Life Sciences - SGGW, Warsaw.

BANASIK K., BARSZCZ M. 2006: Zależności czasów opóźnień odpływu wezbraniowego i rumowiska unoszonego od wybranych charakterystyk zlewni i charakterystyk zdarzeń opad-odpływ (Relationship between the ratio of lag times of runoff and suspended sediment yield and selected basin characteristics and rainfall events). Roczniki Akademii Rolniczej w Poznaniu - CCCLXXV, 3-11 [Engl. summ.].
BANASIK K., BARSZCZ M., HEJDUK L. 2006: Importance of watershed lag times in IUSG development. Sediment Dynamics and Hydromorphology of Fluvial Systems. IAHS Publ. 203, 574-581.

BANASIK K., GÓRSKI D. 1992: Wykorzystanie uniwersalnego równania strat glebowych USLE do oceny ilości rumowiska unoszonego odpływającego z małych zlewni. Gospodarka Wodna nr 3 p. 92 [Engl. summ.].

BANASIK K., IGNAR S., GÓRSKI D. 2000: Modelowanie wezbrań opadowych i jakość odpływu z małych nieobserwowanych zlewni rolniczych. (Modeling flood hydrographs and water quality from small river catchments), Wydawnictwo SGGW, Warsaw.

BANASIK K., MITCHELL J.K. 2008: Conceptual model of sedimentgraph from flood events in a small agricultural watershed. Annals of Warsaw University of Life Sciences - SGGW, Land Reclamation, No 39, 49-57. (http://ann_landreclam.sggw.pl/ z39/art4.pdf). 
BANASIK K., WALLING D.E. 1996: Predicting sedimentgraph for a small agricultural catchment. Nordic Hydrology 27 (4), 275-294.

BHUNYA P.K., JAIN S.K., SIGNH P.K., MISHRA S.K. 2009: A simple conceptual model of sediment yield. Water Resources Management. Vol. 24(8): 1697-1716.

HEJDUK A., 2009: Transport rumowiska unoszonego podczas wezbrań roztopowych w małej zlewni rolniczej (Suspended sediment transport during snowmelt flood events in small agricultural watershed). Unpublished Ph.D.-thesis. Warsaw University of Life Sciences - SGGW.

HEJDUK A., BANASIK K. 2010: Suspended sediment concentration and yield in snowmelt flood events in a small lowland river. Annals of Warsaw University of Life Sciences - SGGW, Land Reclamation, No 42 (1), 61-68. (http://ann_landreclam. sggw.pl/z421/art7.pdf).

HEJDUK L. 2001: Transport rumowiska unoszonego i fosforu w wezbraniach rzeki Zagożdżonki (Suspended sediment and phosphorus transport in flood events in river of Zagożdzonka). Unpublished PhD, SGGW.

HEJDUK L., HEJDUK A., BANASIK K. 2006: Suspended sediment transport during rainfall and snowmelt floods in a small lowland catchment (central Poland). Chapter 9 [in:] Monograph CABI edited by P.N. Owens i A.J. Collins.

SADEGHI S.H.R., SINGH J.K. 2005: Development of a synthetic sediment graph using hydrological data. J. Agric. Sci. Technol. Vol. 7: 69-77.

SCS (Soil Conservation Service), 1986: Urban Hydrology for Small Watersheds. Tech. Report 55, US Dept of Agric., Washington DC, USA.

SINGH P.K., BHUNYA P.K., MISHRA S.K., CHAUBE U.C. 2008: A sediment graph model based on SCS-CN method. Journal of Hydrology. Vol. 349, Issues 1-2: 244-255.
SONNEVELD B., NEARING M. 2003: A nonparametric/parametric analysis of the Universal Soil Loss Equation. Catena 52, p. 9-21.

WILLIAMS J.R. 1978: A sediment graph model based on the instantaneous unit sediment graph. Water Resources Reserch14 (4), 659-664.

Streszczenie: Zarejestrowane czasy opóźnienia wody i rumowiska podczas wezbrań roztopowych $w$ matej zlewni. Czas opóźnienia odpływu wody ( $L a g$ ) oraz czas opóźnienia odpływu rumowiska $\left(\operatorname{Lag}_{s}\right)$ są ważnymi charakterystykami chwilowego hydrogramu jednostkowego - IUH oraz chwilowego sedymentogramu jednostkowego - IUSG. Ich znajomość pozwala na wyznaczenie tzw. parametru transportu rumowiska $B$, będącego kluczowym parametrem IUSG. Badania prowadzono w małej, nizinnej zlewni rzeki Zagożdżonki, położonej $100 \mathrm{~km}$ na południe od Warszawy. Analizie poddano 22 fale roztopowe odnotowane w okresie 1998-2009. Wykorzystując dane pomiarowe ze stacji badawczej w Czarnej, dla wszystkich fal obliczono czasy opóźnienia odpływu wody, a dla 14 spośród ww. fal, dla których posiadano komplet danych, obliczono także czasy opóźnienia odpływu rumowiska. We wszystkich przypadkach czas opóźnienia odpływu rumowiska był mniejszy niż czas opóźnienia odpływu wody, co oznacza, że kulminacja fali rumowiska następowała przed kulminacją fali odpływu wody. Stosunek wartości $\mathrm{Lag}_{s}$ do Lag zawierał się w przedziale 0.41-0.98; wartość średnia wyniosła 0.79 ; odchylenie standardowe 0.17. Dla wszystkich analizowanych zdarzeń stosunek $L_{a g}$ do Lag był mniejszy od 1.

MS. received May 2011

\author{
Authors' address: \\ Agnieszka Hejduk, Kazimierz Banasik \\ Katedra Inżynierii Wodnej - SGGW \\ ul. Nowoursynowska 166 \\ 02-787 Warszawa \\ Poland \\ e-mail: agnieszka_hejduk@sggw.pl \\ kazimierz_banasik@sggw.pl
}

